\title{
Milk composition and its implications in the adult diet
}

\section{By Sheelagh Donovan, Milk Marketing Board, Thames Ditton, Surrey}

In the 50 years since the establishment of the Milk Marketing Board there have been startling changes in the lifestyle and eating habits of UK population. We have passed through an era when food was rationed and choice restricted, into one in which food is plentiful and restrictions are, in the main, self-imposed. The $\mathrm{diet} /$ health interrelationship is now focused not on deficiency but on excess. As a result, dietary guidelines based, in the midst of controversy, on a concensus of medical opinion have been issued to help the professionals, to help consumers to help themselves. Unfortunately, attempts to express these guidelines in practical terms have led many consumers not to evaluate their diet as a whole but to see it as composed of good and bad foods. Milk and a number of milk products have tended to fall into the latter category.

Alongside this issue, there is concern about the adequacy of the diet of families of the unemployed and those on a restricted income. The erratic eating habits of older teenagers and the expansion of the wine, soft drinks, crisps, snack foods, 'take-away' and chocolate bar markets also give cause for concern.

Milk composition and its implications in the adult diet will therefore be discussed in the context of the diet as a whole, bearing in mind current trends in eating habits and Department of Health and Social Security recommendations for the population in general.

\section{The changing role of milk and milk products in the UK diet}

In human nutrition, it is changes in patterns of milk and milk product consumption, rather than the slight changes in milk composition, that reflect the dietary significance of milk constituents.

In the UK, the National Food Survey (compiled by the Ministry of Agriculture, Fisheries and Food) monitors the adequacy of the household diet, the nutritional contribution made by different foods, and differences between households of varying income, family structure and locality. However, there is an 18 month interval between collection of information and publication of detailed analysis. Table I shows that, in 1980 , liquid milk remained the most significant of all milk products despite a gradual reduction in consumption since 1975 (Ministry of Agriculture, Fisheries and Food, 1982). It also highlights the relatively high contribution of 'minor' nutrients from milk-while supplying only $10 \%$ total energy and $13 \%$ total fat, it contributed far more calcium, protein and vitamin $B_{2}$. Cheese consumption altered little and it continued to be a significant source of $\mathrm{Ca}$. It is the regular consumption of milk, cheese or yoghurt that helps to ensure that Ca needs are met, particularly in soft water areas. Butter contributed only $5 \%$ of total energy in 1980 . Changes in buying patterns and average consumption of 
Table I. Per cent energy and nutrients per person contributed by dairy products in the average household diet in the UK (Ministry of Agriculture, Fisheries and Food, r982)

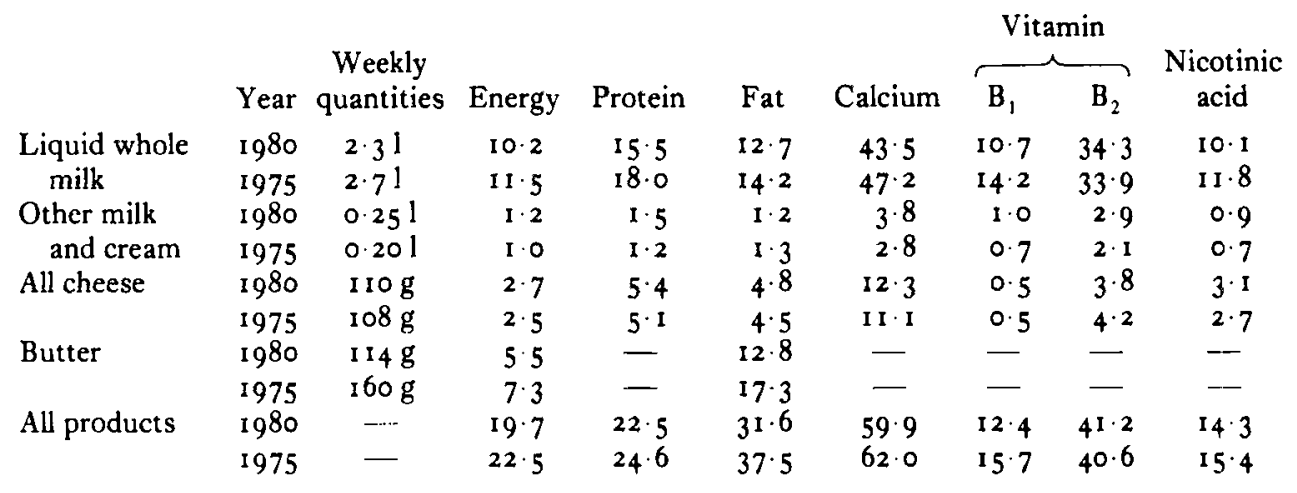

Table 2. Buying patterns and consumption per person in the average household and in households of differing family structure and income in the UK (Ministry of Agriculture, Fisheries and Food, 1982)

\begin{tabular}{|c|c|c|c|c|c|c|c|}
\hline \multirow[b]{2}{*}{ Income level... } & \multirow[t]{2}{*}{ Year } & \multirow[t]{2}{*}{$\begin{array}{c}\text { \%ouseholds } \\
\text { buying }\end{array}$} & \multirow[t]{2}{*}{$\begin{array}{c}\text { Average } \\
\text { intake }\end{array}$} & \multicolumn{2}{|c|}{$\begin{array}{r}\begin{array}{l}\text { Two adults }+ \\
\text { three children }\end{array} \\
\end{array}$} & \multicolumn{2}{|c|}{ Two adults } \\
\hline & & & & A & $\mathrm{C}$ & A & $\mathrm{C}$ \\
\hline \multirow[t]{2}{*}{ Liquid milk (l) } & 1975 & 97 & $2 \cdot 7$ & $2 \cdot 45$ & $2 \cdot 4$ & $2 \cdot 85$ & $2 \cdot 8$ \\
\hline & 1980 & 97 & $2 \cdot 3$ & $2 \cdot 2$ & 2. I & $2 \cdot 45$ & 2.4 \\
\hline \multirow[t]{2}{*}{ Cream (ml) } & 1975 & 24 & 20 & I 5 & 5 & 65 & 25 \\
\hline & 1980 & 18 & 20 & I5 & 10 & 55 & 20 \\
\hline Butter (g) & $\begin{array}{l}1975 \\
1980\end{array}$ & $\begin{array}{l}75 \\
55\end{array}$ & $\begin{array}{l}160 \\
115\end{array}$ & $\begin{array}{l}130 \\
100\end{array}$ & $\begin{array}{r}100 \\
60\end{array}$ & $\begin{array}{l}195 \\
165\end{array}$ & $\begin{array}{l}190 \\
145\end{array}$ \\
\hline \multirow[t]{2}{*}{ Total 'yellow fats' (g) } & 1975 & - & 235 & 170 & 190 & 275 & $\begin{array}{l}283 \\
280\end{array}$ \\
\hline & 1980 & - & 225 & 185 & 175 & 280 & 255 \\
\hline \multirow[t]{2}{*}{ Processed cheese $(\mathrm{g})$} & 1975 & 15 & 9 & 5 & 5 & 10 & 10 \\
\hline & 1980 & 12 & $6 \cdot 5$ & 5 & 5 & 5 & 10 \\
\hline \multirow[t]{2}{*}{ Natural cheese (g) } & I975 & 50 & 97 & 70 & 60 & 160 & 125 \\
\hline & I980 & $5^{\circ}$ & 103 & 95 & 75 & 150 & 125 \\
\hline \multirow[t]{2}{*}{ Yoghurt (ml) } & 1975 & 14 & 20 & - & - & - & - \\
\hline & 1980 & 23 & 40 & - & - & - & $\cdots-\cdots$ \\
\hline \multirow[t]{2}{*}{ Soft cheese (g) } & 1975 & 6 & 5 & 一 & - & - & 一 \\
\hline & 1980 & 10 & 10 & - & - & - & - \\
\hline
\end{tabular}

major milk products were also evident as were differences in consumption between households of differing family structure and income (Table 2) (Ministry of Agriculture, Fisheries and Food, 1982). The findings are summarized as follows:

r. Most households continued to buy fresh milk but weekly consumption was less per capita in large households. 
2. Household penetration and consumption of cream remained low, even among the more affluent 'two adult' households: they averaged about 4 tablespoons/ person per week while others averaged about 3-4 teaspoons/person per week.

3. Less butter was used in fewer households but income and family structure affected the quantities consumed: this fall reflected a decreased share of the 'yellow fats' market rather than an over-all reduction in spreading-fat usage.

4. Household penetration of natural cheese remained constant but income and family structure affected quantities consumed: there was a $20 \mathrm{~g}$ difference between income groups and a $50 \mathrm{~g}$ difference between 'adults only' and 'adults plus three children' households.

5. Yoghurt and cottage cheese, though increasingly popular, had relatively low household penetration and consumption levels.

There is, therefore, evidence of 'between household' variation in consumption of a number of milk products.

\section{The significance of differences in dairy produce consumption}

When a wide variety of foods can be eaten, it could be said that the nutritional significance of any food is largely dependent on the composition of the rest of the diet. To ignore items outside the scope of the National Food Survey-alcohol, confectionery, soft drinks and between-meal food and drink eaten outside the home-and consider dairy produce in isolation, could therefore mask their true significance in the diet of certain sectors of the community. Appreciation of this principle also makes it more difficult to give advice to the general population, particularly if changes in consumption of milk products of high nutrient density are to be recommended. It is therefore vital to evaluate the diet as a whole and identify consumer profiles and target audiences before embarking on a nutrition education programme.

\section{Within-household consumption of milk and related products}

It is possible to speculate on the food consumption of individual family members and to monitor trends in eating patterns both inside and outside the home by examing market research data. As milk, cheese and butter are rarely eaten alone, consumption of these high household penetration foods is largely dependent on the serving of other foods.

\section{Liquid milk}

Whole milk (average $3^{8} \mathrm{~g}$ butterfat/l) is the traditional choice in the UK but semi-skimmed (average $15 \mathrm{~g}$ butterfat/l) and skimmed (average I $g$ butterfat/l) milk are also available. Household consumption accounts for about $90 \%$ of the liquid market (Attwood Statistics Ltd, 1978 and 1982), a market in which there are four major sectors. 
Milk drinking. Unflavoured or white milk accounts for only $13 \%$ household consumption. Children under ro years, traditionally the heaviest milk drinkers, have reduced their milk intake while increasing their consumption of soft drinks (Table 3). Flavoured milk, although increasing in popularity is, in volume terms, only $1.5 \%$ of the total liquid-milk market.

Milk in beverages. By far the greatest proportion ( $43 \%$ total) is served in tea or coffee. The decline in the volume of milk used in this way has followed the trend towards coffee rather than tea drinking, since there is a tendency to add less millk to coffee, to use a 'whitener' or to drink black coffee. Increasing numbers of centrally-heated homes and later eating of the evening meal is thought to have adversely affected consumption of bedtime milk drinks.

Milk on cereals. An increasing proportion ( $17 \%$ market) is being served at breakfast. Young families in social groups $A B$ and $C_{I}$ serve cereals most frequently, although there must be considerable variation in the volume of milk poured over cereals.

Milk in cooking. Only $12 \%$ is used in cooking, primarily in sweet recipes.

\section{Hard cheese and butter}

Major consumers of these products are regular eaters of toast, sandwiches and crackers- $63 \%$ cheese and over $75 \%$ butter is served with these foods (TaylorNelson Ltd, 1979). Individuals who are tea drinkers and regularly eat breakfast cereals, buttered toast and sandwiches are, therefore, likely to be the major consumers of milk, cheese and butter. This may seem obvious but consumers whose confidence in milk and traditional milk products has been undermined in recent years do not always think in these terms; they do not necessarily consider how significantly these foods feature in their diet nor view consumption in the context of their diet as a whole.

The consumer profile of the low household penetration products, e.g. cream, cottage cheese and yoghurt is more closely defined.

\section{Cream}

Household consumption accounts for only $31 \%$ of the total cream market. Cream is rarely eaten everyday. Consumption peaks twice a year-in the soft

Table 3. Trends in white milk and soft drink consumption (l/person per week) in different age groups in the UK (Nestle Market Research Department, 1970-1982)

\begin{tabular}{|c|c|c|c|c|}
\hline \multirow{2}{*}{$\begin{array}{l}\text { Age (years) } \\
\text { Period of survey ... }\end{array}$} & \multicolumn{2}{|c|}{ Milk } & \multicolumn{2}{|c|}{ Soft drinks } \\
\hline & $1970-71$ & $1980-81$ & $1974-75$ & $198 I-82$ \\
\hline $2-9$ & $\mathrm{I} \cdot 6$ & $I \cdot 2$ & $1 \cdot 8_{5}$ & 2.6 \\
\hline $10-15$ & 0.7 & 0.5 & $1 \cdot 2$ & $I \cdot 9$ \\
\hline $16-24$ & 0.45 & 0.4 & $1 \cdot 0$ & $I \cdot 15$ \\
\hline $25-64$ & 0.27 & 0.11 & 0.5 & 0.65 \\
\hline $65+$ & 0.17 & 0.17 & 0.25 & 0.22 \\
\hline
\end{tabular}


fruit season and at Christmas. Middle-aged purchasers ( $5 \circ$ years and over) account for $59 \%$ of the household market.

\section{Cottage cheese}

Sales are highest in the summer and although usually bought when slimming, it frequently becomes a purchase in its own right. A typical eater is a 35 to 50-year-old woman in social group AB (social group $\mathrm{AB}$ accounts for $16 \%$ of the UK population) and in only about a third of such households do other members also eat cottage cheese (Attwood Statistics Ltd, 1978 and 1982 ).

\section{Yoghurt}

Fruit yoghurt appears to have little social class bias and it is particularly popular in the London area and in households with children. Only $23 \%$ of households buy yoghurt weekly but it has been tried by over $60 \%$ of housewives (Mintel Publications Ltd, 1982a,b). Yoghurt is most frequently eaten at mealtimes, although a recent survey showed its emergence as an at home snack (it was eaten on 9 million meal occasions representing $4 \%$ of total snacks (Taylor-Nelson Ltd, 1978 and 1982)) (Table 4). Fresh fruit was eaten more often as a snack and represented 298 million meal occasions. The number of occasions when chocolate biscuits were eaten as a snack has increased since 1977 , as has the consumption of crisps and nuts, consumption, increasing from 65 million meal occasions to 136 million occasions in 1982 .

\section{Natural yoghurt}

This accounts for only $8 \%$ of the yoghurt market with only one-third of housewives admitting they have ever bought it (Mintel Publications Ltd, 1982a,b). It is most popular with women in social groups $A B$ and $\mathrm{Cr}$.

Table 4. Serving occasions of various snack foods in the UK (Taylor-Nelson Ltd, $\mathrm{r} 978$ and $\mathrm{I982}$ )

\begin{tabular}{|c|c|c|c|c|}
\hline \multirow{2}{*}{$\begin{array}{l}\text { Food item } \\
\text { Period of survey ... }\end{array}$} & \multicolumn{2}{|c|}{$\begin{array}{c}\% \text { Occasions } \\
\text { mentioned as a snack }\end{array}$} & \multicolumn{2}{|c|}{$\begin{array}{c}\text { Millions of meal } \\
\text { occasions this represents }\end{array}$} \\
\hline & $\begin{array}{l}\text { Winter } 1977^{-} \\
\text {spring } 1978\end{array}$ & $\begin{array}{l}\text { Winter } 1981- \\
\text { spring } 1982\end{array}$ & $\begin{array}{c}\text { Winter } 1977^{-} \\
\text {spring } 197^{8}\end{array}$ & $\begin{array}{l}\text { Winter } 1981- \\
\text { spring } 1982\end{array}$ \\
\hline Semi-sweet biscuit & 74 & 71 & 133 & 131 \\
\hline Chocolate coated biscuit & $5^{6}$ & $5^{8}$ & 66 & 85 \\
\hline Countline biscuit & $5^{I}$ & 49 & $6 \mathrm{I}$ & 98 \\
\hline Crisps/nuts & $4 I$ & $5^{2}$ & 65 & 136 \\
\hline Fresh fruit & 8 & 19 & 97 & 298 \\
\hline Yoghurt & 2 & 4 & 3 & 9 \\
\hline
\end{tabular}




\section{'Out-of-home' consumption of milk and related products}

Traditional dairy products have only a minor role to play since school, industrial and high street caterers and food manufacturers together are estimated to account for only $10 \%$ of the liquid milk market and $13 \%$ of the cheese market. However, fast-food chains are making pizzas, cheeseburgers and 'thick shakes' more familiar to inhabitants of cities and metropolitan areas. A survey conducted in June $\mathbf{1 9 8 2}$ (Mintel Publications Ltd, $1982 b$ ) indicated that during a 4 -week period, about $75 \%$ of the respondents had made at least one purchase of 'take away' foods, a figure that rose to $93 \%$ among $15^{-24}$ year olds.

Table 5 indicates that burger outlets, where the majority of 'thick shakes' are purchased, were popular among the under $25 \mathrm{~s}$. Fish and chips were the most popular take-away, although chips alone appealed particularly to the under $25^{8}$. The popularity of pizzas is masked because over $60 \%$ of purchases are eaten on the premises (Euromonitor, 1982). Most 'take-away' meals are eaten at home, although the under 20 are as likely to eat them in the street or car (Table 6).

\section{Significance of eating pattern trends}

An in depth look at consumption of milk and related products has shown that they will differ in significance in individual diets, with consumption in many cases determined by the popularity of other foods or drink, and likely to vary according to social group, lifestyle, age, sex and season.

Recent market research results have highlighted an encouraging increase in the popularity of fruit as a snack. However, it also indicated increasing consumption of chocolate biscuits, soft drinks, crisps and nuts which, if bought and eaten outside the home, would escape detection by the National Food Survey; as would 'out-of-

Table 5. Percentage of respondents purchasing 'take-away' meals (Euromonitor, 1982)

$\begin{array}{lccccc} & \begin{array}{c}\text { Burgers } \\ \text { chips }\end{array} & \begin{array}{c}\text { Chips } \\ \text { alone }\end{array} & \text { Chinese } & \text { Pizza } \\ \text { All } & \text { I6 } & 49 & 21 & 25 & 8 \\ \text { I5-19 year olds } & 31 & 56 & 45 & 33 & 17 \\ \text { 20-24 year olds } & 28 & 56 & 35 & 42 & 16 \\ \text { 25-34 year olds } & 20 & 57 & 28 & 33 & 8 \\ 35-44 \text { year olds } & 15 & 52 & 18 & 32 & 7 \\ \text { London/South } & 23 & 39 & 18 & 23 & 11 \\ \text { Yorkshire/North-east } & 16 & 60 & 23 & 25 & 6\end{array}$

Table 6. Where take-away meals are eaten (\% of total) (Euromonitor, 1982)

All

15-19 year olds

20-24 year olds

25-34 year olds
At home

83

$5^{8}$

85

89
In car

$\begin{array}{lr}11 & 10 \\ 12 & 42 \\ \text { II } & 12 \\ 15 & 5\end{array}$


home' eating of 'take-away' foods. Many of these foods, which have a low nutrient density or a relatively high fat content or both, have become part of the peer group food culture of teenagers and young adults, so making it more difficult to effect moderation.

A preponderance of low-nutrient-density or relatively high-salt items in the diet of any sector of the community would give cause for concern (McGregor, 1983 ). It is therefore important to ensure that confidence in high-nutrient-density foods, such as milk, is maintained and that such foods retain their position as core foods in the UK diet.

\section{Department of Health and Social Security dietary guidelines for the UK}

It is important to consider the role of milk and milk products in the diet of those whose over-all nutrient intake contravenes dietary recommendations for the general population. A recent British Nutrition Foundation (1982) monograph presents an overview of this complex issue.

The Department of Health and Social Security (1979), in their publication Eating for Health, have recommended the following: eat a wide variety of foods; avoid obesity; avoid excessive reliance on fatty and sugary foods; compensate, if necessary, for a reduction in the above foods by eating more cereal foods, pulses, potatoes, other vegetables and fruit; moderate intake of salt; moderate consumption of alcohol. Two of these recommendations will be considered with particular reference to dairy produce.

\section{Avoid excessive intake of fatty foods}

General advice to moderate fat and energy intake from dairy products frequently recommends a change from full-fat to reduced-fat products and the avoidance of cream. Although this in itself would not adversely affect the nutritional quality of the diet, it appears to suggest that individual variations in consumption and food preferences can be dismissed as inconsequential, a view not held by McKenzie (1979) who considers palatability a key factor for consideration.

Liquid milk. The high household penetration of liquid milk makes changing from whole to reduced-fat milk appear a convenient way to reduce fat and energy intake. Yet the impact of such a change for individuals will be solely dependent on the quantity used and the composition of the rest of the diet. If the National Food Survey results are used, replacing the average consumption of 0.31 whole milk/ head per week by semi-skimmed milk would save $8 \mathrm{~g}$ fat and $300 \mathrm{~kJ}$ ( $70 \mathrm{kcal}$ ), while substituting with skimmed milk would save $12.5 \mathrm{~g}$ fat and $470 \mathrm{~kJ}$ ( II5 kcal).

Table 7. Fat and energy contents of popular foods (Paul ङ゚ Southgate, 1978)

$\begin{array}{lccc}\text { Food } & \text { Weight }(\mathrm{g}) & \text { Fat }(\mathrm{g}) & \text { Energy (kJ) } \\ \text { Packet crisps } & 25 & 9.0 & 555 \\ \text { Packet peanuts } & 25 & 12.5 & 590 \\ \text { Portion chips } & 150 & 11-22 & 1065-1645 \\ \text { Bar chocolate } & 40 & 12 & 885\end{array}$


The significance of this change is put into perspective when foods shown to be increasingly popular are considered (Table 7). These points emphasize the need to equip individuals to evaluate their diet as a whole, so that they can decide whether their consumption of fatty foods is excessive and how best to moderate intake.

It must be remembered that the flavour of reduced-fat milks may not appeal to everyone. Palatability could be the crucial factor affecting the use of milk on cereals and hence cereal consumption itself, while sugar consumption would increase if flavoured milk were preferred to white milk. Care should therefore be taken to ensure that those for whom milk is a significant source of a range of nutrients are not led to believe that whole milk is a food to be avoided. These points should be considered when extolling the virtues of reduced-fat milk.

Cheese. Full-fat, hard cheese currently accounts for $93 \%$ of the cheese market, although medium-fat cheese is also available. The average daily intake of $15 \mathrm{~g} / \mathrm{d}$ makes it more appropriate to consider cheese in terms of portion size. A $100 \mathrm{~g}$ portion of medium-fat cheese and a $75 \mathrm{~g}$ portion of full-fat cheese have similar energy ( $1.2 \mathrm{MJ}(300 \mathrm{kcal})$ ) and fat contents (23 and $25 \mathrm{~g}$ respectively; Paul \& Southgate, 1978). Should a preference for full-fat cheese be expressed, portion size rather than type can be used to control fat and energy intake. Low-fat, cottage cheese is not seen as a substitute for hard cheese and its present appeal to only a relatively small sector of the population also limits its potential for reducing over-all fat and energy intake.

Cream. The fat content of cream varies according to the type chosen (Table 8) and when whipped, double cream almost doubles its volume, while whipping cream at least doubles its volume. For the relatively few whose diet frequently includes large amounts of cream, suggesting that they serve whipped cream or cream with a lower fat content would be more likely to elicit a response than recommending that they try yoghurt instead. It should not be forgotten that for the majority of people, cream is an insignificant, spasmodic source of fat, used to enhance the enjoyment of food on special occasions.

Butter. Legally, both butter and margarine must contain a minimum of $800 \mathrm{~g}$ fat $/ \mathrm{kg}$. The significance of these foods as sources of fat is largely dependent on the eating of toast and sandwiches and the generosity with which fat is spread. The fat and energy contents of the diet will only be reduced if less 'spreading fat' is eaten.

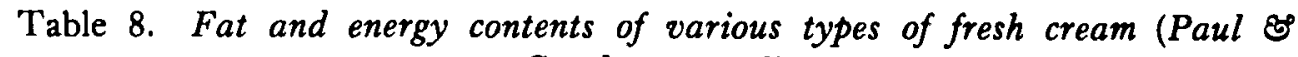
Southgate, 1978)

(Minimum fat content $(\mathrm{g} / \mathrm{kg})$ in parentheses)

I Tablespoon of:

Fat (g) Energy (kJ)

Single cream ( 180$)$

Whipping cream (350)

Double cream (480)

Whipped whipping cream

$\begin{array}{ll}3 & 125 \\ 5 & 200 \\ 7 & 260 \\ 2 \cdot 5 & 105\end{array}$


Table 9. Salt content of various cheeses ( $\mathrm{g} \mathrm{NaCl} / \mathrm{kg}$; Paul \& Southgate, 1978)

$\begin{array}{lccccc}\text { Type... } & \text { Cheddar } & \text { Edam } & \text { Blue Stilton } & \text { Camembert } & \text { Danish blue } \\ \text { Salt content } & 6.1 & 9.8 & 11.5 & 14.1 & 14.2\end{array}$

\section{Moderate intake of salt}

Table salt, cereal and meat products are the major sources of salt in the average diet, with liquid milk providing only $5 \%$ and cheese, cream, ice cream and fats only II \% of total intake (British Nutrition Foundation, 198I). Unsalted butter is available, although salted varieties $(15-35 \mathrm{~g} \mathrm{NaCl} / \mathrm{kg}$ ) are the preferred $\mathrm{UK}$ choice. Salt influences the flavour of cheese but more important is its effect on the growth of micro-organisms during ripening and storage. Blue, soft French and medium-fat hard cheeses have a higher salt content than Cheddar (Table 9), so advising a change to cheese with a lower fat content would simultaneously increase salt intake. Attempts have been made to produce hard cheese with salts other than sodium chloride but with varying success (Naudts, I98I).

\section{Conclusion}

Having reviewed the role of milk and related products in the light of current trends in eating habits and Department of Health and Social Security guidelines, the following conclusions can be drawn: various milk products, and hence millk constituents, differ in significance in individual diets. Although consumption is in the main determined by the popularity of other food and drink and likely to vary according to social group, lifestyle, age, sex and season; milk, cheese and yoghurt can make significant contributions to intakes of protein, $\mathrm{Ca}$, riboflavin and other $\mathrm{B}$ vitamins. Although it has proved technologically feasible to produce milk and milk products with a reduced fat content, this is not the only form in which they can play a useful role in the UK diet. It is always possible to reduce the intake of a food constituent by eating less of the foods concerned. It is rarely necessary, for reasons other than lack of willpower, to avoid particular foods altogether. When it is known that there are no good and bad foods, simply good and bad diets, consumers must not be led to believe that the path to good nutrition is obstructed by foods they must avoid at all costs and littered with others that initiate a feeling of guilt whenever they are encountered. They should be encouraged to evaluate their diet as a whole and to view foods in terms of the frequency with which they are eaten and the size of portion served. It is surely sensible to present dietary modifications in terms likely to be considered and then, hopefully, adopted rather than confront individuals with over-simplifications of the 'truth' which, as knowledge increases, may need revision and which experience shows are likely to be misinterpreted or rejected. With our ever-increasing awareness of the sociological factors affecting food choice and our desire to help consumers to help themselves, will long-term interests be best served by messages that suggest little or no place in the diet for full-fat milk products? 


\section{REFERENCES}

Attwood Statistics Ltd (1978 and 1982). A Continuous Panel Survey. Details available from Milk Marketing Services Economics Division, Milk Marketing Board, Thames Ditton, Surrey or Attwood Statistics Ltd, Berkhamsted, Herts.

British Nutrition Foundation (1981). Briefing Paper: Salt in the Diet. London: British Nutrition Foundation.

British Nutrition Foundation (1982). Implementation of Dietary Guidelines-Obstacles and Opportunities. London: British Nutrition Foundation.

Department of Health and Social Security (1979). Eating for Health. London: H.M. Stationery Office.

Euromonitor (1982). Market Research Great Britain. London: Euromonitor Publications.

McGregor, G. A. (1983). Lancet i, $75^{\circ}$.

McKenzie, J. C. (1979). Proc. Nutr. Soc. 38, 2 19.

Ministry of Agriculture, Fisheries and Food (1982). Household Food Consumption and Expenditure: 1980. Annual Report of National Food Survey Committee. London: H.M. Stationery Office.

Mintel Publications Ltd ( $982 a$ ). Dairy Produce. Details available from Milk Marketing Services Economics Division, Milk Marketing Board, Thames Ditton, Surrey or Mintel Publications Ltd, London.

Mintel Publications Ltd $(1: 82 b)$. Fast Food Survey. Details available from Milk Marketing Services Economics Division, Milk Marketing Board, Thames Ditton, Surrey or Mintel Publications Ltd, London.

Naudts, M. (1981). Lait et Nous 3, 26.

Nestle Market Research Department (1970-1982). National Drinks Survey-A Continuous Panel Survey. Details available from Milk Marketing Services Economics Division, Milk Marketing Board, Thames Ditton, Surrey or Nestle Market Research Department.

Paul, A. \& Southgate, D. A. T. (1978). McCance and Widdowson's The Composition of Foods. London: H.M. Stationery Office.

Taylor-Nelson Ltd (1979). Cheese Usage Study. Details available from Milk Marketing Services Economics Division, Milk Marketing Board, Thames Ditton, Surrey or Taylor-Nelson Ltd, Epsom, Surrey.

Taylor-Nelson Ltd (1978 and 1982). Family Food Panel-A Continuous Panel Survey. Details available from Milk Marketing Services Economics Division, Milk Marketing Board, Thames Ditton, Surrey or Taylor-Nelson Ltd, Epsom, Surrey. 